\title{
RP-HPLC method development and validation for estimation of rivaroxaban in pharmaceutical dosage forms
}

\author{
Mustafa Çelebier, Tuba Reçber, Engin Koçak, Sacide Altınöz* \\ Department of Analytical Chemistry, Faculty of Pharmacy, Hacettepe University, Turkey
}

\begin{abstract}
Rivaroxaban, an anti-clotting medication, acts at a crucial point in the blood-clotting process and stops the formation of blood clots. In this study, RP-HPLC method was developed for the determination of rivaroxaban in tablets (Xarelto $\left.{ }^{\circledR}(10 \mathrm{mg})\right)$. Phenomenex Luna $5 \mu \mathrm{m} \mathrm{C18} 100 \AA$ LC Column $(250 \mathrm{x} 4.6 \mathrm{~mm})$ was used at $40{ }^{\circ} \mathrm{C}$. Isocratic elution was performed with ACN:Water $(55: 45 \mathrm{v} / \mathrm{v})$ mixture. The flow rate was $1.2 \mathrm{~mL} \mathrm{~min}^{-1}$ and UV detection was at $249 \mathrm{~nm}$. Internal standard (Caffeine) and rivaroxaban were eluted within 2.21 and 3.37 minutes, respectively. The developed method was validated according to the ICH guidelines and found to be linear within the range $0.005-40.0 \mu \mathrm{g} \mathrm{mL}^{-1}$. The method was accurate, precise, robust and rapid. Thus, it was applied successfully for the quality control assay of rivaroxaban in tablet dosage form.
\end{abstract}

Uniterms: HPLC. Rivaroxaban. Validation. System suitability. Stability-indicating. Pharmaceutical dosage form.

\begin{abstract}
Rivaroxabana, fármaco anticoagulante, atua em um ponto crucial no processo de coagulação do sangue e impede a formação de coágulos sanguíneos. Neste estudo, desenvolveu-se método de RP-HPLC para a determinação de rivaroxabana em comprimidos (Xarelto ${ }^{\circledR}(10 \mathrm{mg})$ ). Utilizou-se coluna LC ( 250 x 4,6 mm) Phenomenex Luna C18 $5 \mu \mathrm{m} 100 \AA$ a $40{ }^{\circ} \mathrm{C}$. Realizou-se eluição isocrática com ACN: água (55:45 v/v). O fluxo foi de 1,2 mL min-1 e a detecção de UV foi a $249 \mathrm{~nm}$. Padrão interno (cafeína) e rivaroxabana eluíram em 2,21 e 3,37 minutos, respectivamente. O método desenvolvido foi validado de acordo com as diretrizes do ICH e mostrou-se linear na faixa $0,005-40,0 \mathrm{mg} \mathrm{mL}^{-1}$. O método foi exato, preciso, robusto e rápido. Assim, foi aplicado com êxito para o ensaio de controle de qualidade da Rivaroxabana na forma de comprimidos.
\end{abstract}

Unitermos: HPLC. Rivaroxabana. Validação. Adequação do sistema. Indicador de estabilidade. Forma farmacêutica.

\section{INTRODUCTION}

Anticoagulants are given to prevent the blood from clotting or prevent to existing clots from getting larger. Clots can block the blood flow to the heart muscle or block the blood flow to the brain. These cause a heart attack or a stroke. Rivaroxaban (RIV), an oral oxazolidinone-based anticoagulant, is a potent, selective direct inhibitor of factor Xa that is used in the prevention of venous thromboembolism in adult patients after total hip replacement or total knee replacement surgery. RIV

*Correspondence: S. Altınöz. Hacettepe University, Faculty of Pharmacy, Department of Analytical Chemistry. 06100 - Ankara- Turkey. E-mail: saltinoz@hacettepe.edu.tr
(Figure 1) is a small molecule (molecular mass: $436 \mathrm{~g}$ $\mathrm{mol}^{-1}$ ) that is almost insoluble in water and exhibits high plasma protein binding (92-95\%) in humans, with serum albumin being the main binding component.

The potency of factor Xa inhibition occurs primarily<smiles>O=C(NCC1CN(c2ccc(N3CCOCC3=O)cc2)C(=O)O1)c1ccc(Cl)s1</smiles>

FIGURE 1 - Chemical structure of rivaroxaban. 
as a result of RIV binding with high selectivity to the S1 and S4 pockets of the serine endopeptidase (Duggan et al., 2009). Inhibition of factor Xa interrupts the intrinsic and extrinsic pathway of the blood coagulation cascade, inhibiting both thrombin formation and development of thrombi. RIV does not inhibit thrombin (activated Factor II), and has no effects on platelets have been demonstrated (Pezborn et al., 2007; Terry et al., 2009). The RIV was approved for marketing by Health Canada and European Commission in 2008. In the literature, there is an HPLCMS method for the determination of RIV in human plasma for pharmacokinetic studies (Rohde, 2008). However, there is no method reported for the quantification of RIV in pharmaceutical dosage forms. It is well known that quality control is an important task in the pharmaceutical industry. The term quality control refers to the sum of all procedures undertaken to ensure the identity and purity of a particular pharmaceutical (WHO, 2010). Quality control measurements include stability testing of the drug formulation, dissolution testing and analysis of raw materials and synthesis products. A pharmaceutical company usually has to measure a large number of quality control samples and HPLC is a unique technique for the analysis of wide variety of samples (Dong, 2005). In this study, it was aimed to develop an accurate, precise, robust, rapid and selective HPLC method for determination of RIV in tablet dosage forms. The stability of RIV was evaluated and also a forced degradation procedure was applied under stress conditions like high temperature, acidic-alkali conditions, and irradiation with UV light. The developed method was fully validated according to the ICH (ICH, 2005) guidelines and observed that it was capable of determining RIV in the presence of forced degradation products. Therefore, it could be concluded that this method could be proposed for the quality control process of RIV in pharmaceutical industry.

\section{MATERIAL AND METHODS}

\section{Chemicals and reagents}

RIV working standard was supplied from Refik Saydam Hifzısıhha National Public Health Agency. The tested pharmaceutical formulations (Xarelto ${ }^{\circledR} 10 \mathrm{mg}$, (approved in Canada, 2008) were procured from Bayer Turkey. Acetonitrile (ACN) was analytical grade and purchased from Merck.

\section{Apparatus and Chromatographic conditions}

HPLC analyses were performed on a Shimadzu UFLC system. Separations were carried on a Phenomenex Luna $5 \mu \mathrm{m} \mathrm{C} 18100 \AA$ LC Column $(250 \mathrm{x} 4.6 \mathrm{~mm})$. The column temperature was set at $40^{\circ} \mathrm{C}$ and the flow rate was $1.2 \mathrm{~mL} \mathrm{~min}^{-1}$ while using isocratic elution with ACN:Water $(55: 45 \mathrm{v} / \mathrm{v})$ mixture. Injection volume was $5 \mu \mathrm{L}$ and UV detection was performed at $249 \mathrm{~nm}$. Peak identity was confirmed by retention time comparison.

\section{Preparation of standard solution}

The standard stock solution of RIV $\left(1000 \mu \mathrm{g} \mathrm{mL}^{-1}\right)$ was prepared in ACN:Water $(80: 20 \mathrm{v} / \mathrm{v})$ mixture. The working standard solutions $(5.0,10.0,20.0,25.0,30.0$, 35.0 and $40 \mu \mathrm{g} \mathrm{mL}^{-1}$ ) were prepared by diluting the stock solution in the mobile phase solution. The stock solution was kept at $+4{ }^{\circ} \mathrm{C}$ where it is stable at least one month. Standard solutions were daily prepared by diluting the stock solution with mobile phase solution.

\section{Preparation of sample solution}

Ten tablets were weighed to get the average weight and grounded. An amount of powder equivalent to $10 \mathrm{mg}$ of RIV was transferred to a $100 \mathrm{~mL}$ volumetric flask and added $70 \mathrm{~mL}$ of diluent (ACN:Water $(80: 20 \mathrm{v} / \mathrm{v}))$ and sonicated for $30 \mathrm{~min}$. The volume was made up with solvent to obtain a solution containing $100 \mu \mathrm{g} \mathrm{mL}^{-1} \mathrm{RIV}$. An aliquot was then removed and centrifuged at $5000 \mathrm{rpm}$ for $10 \mathrm{~min}$. The solution was filtered using $0.45 \mu \mathrm{m}$ membrane filter paper and diluted with mobile phase to $20 \mu \mathrm{g} \mathrm{mL}^{-1}$ before injected to the HPLC system.

\section{Preparation of analytical placebo solution}

Common inactive ingredients such microcrystalline cellulose $(10 \%, 500 \mathrm{mg})$, anhydrous dibasic calciumphosphate $(83 \%, 4150 \mathrm{mg})$, croscarmellose sodium $(5 \%, 250 \mathrm{mg})$, colloidal silicon dioxide (\%1, $50 \mathrm{mg})$, and magnesium stearate $(\% 1,50 \mathrm{mg})$ were weighed according to the ratios in a common tablet formulation to achieve $5 \mathrm{~g}$ of bulk. Then, approximately $1 \mathrm{~g}$ of this bulk was used to prepare the analytical placebo solutions by applying the same procedure on preparation of tablet solutions. Synthetic tablet solutions were prepared by adding known amounts of RIV standard solutions to the analytical placebo solutions.

\section{Forced Degradation}

\section{High Temperature} $100 \mu \mathrm{L}$ of RIV standard stock solution was diluted 
to $1000 \mu \mathrm{L}$ by adding water. The concentration of RIV was $100 \mu \mathrm{g} \mathrm{mL}^{-1}$ in the final solution. Then the solution was transferred to a centrifuge tube and kept in a water bath for $2 \mathrm{~h}$ at $80^{\circ} \mathrm{C}$. The solution was cooled to room temperature $\left(25 \pm 5^{\circ} \mathrm{C}\right)$, and then it was diluted with mobile phase to $20 \mu \mathrm{g} \mathrm{mL}^{-1}$ and injected into the HPLC system.

\section{Acid and alkali hydrolysis}

$100 \mu \mathrm{L}$ of RIV standard stock solution was diluted to $1000 \mu \mathrm{L}$ by adding $0.1 \mathrm{~N}$ hydrochloric acid, or $0.1 \mathrm{~N}$ sodium hydroxide. The concentration of RIV was $100 \mu \mathrm{g} \mathrm{mL}^{-1}$ in the final solution. Then the solution was transferred to a centrifuge tube and kept in a water bath for $2 \mathrm{~h}$ at $40{ }^{\circ} \mathrm{C}$. These solutions were cooled at room temperature $\left(25 \pm 5^{\circ} \mathrm{C}\right)$, after they were neutralized with suitable amount of hydrochloric acid or sodium hydroxide. The solutions were diluted with mobile phase to $20 \mu \mathrm{g} \mathrm{mL}^{-1}$ and injected into the HPLC system.

\section{Irradiation with ultraviolet light}

$100 \mu \mathrm{L}$ of RIV standard stock solution was diluted to $1000 \mu \mathrm{L}$ by adding water. The concentration of RIV was $100 \mu \mathrm{g} \mathrm{mL}^{-1}$ in the final solution. The solution was exposed to UV light $(254 \mathrm{~nm})$ combined with tungsten lamp for 24 hours at room temperature. The solution was then diluted with mobile phase to $20 \mu \mathrm{g} \mathrm{mL}^{-1}$ and injected into the HPLC system.

\section{Stability studies}

The purpose of stability testing is to provide evidence on how the quality of drug product varies with time under the influence of a variety of environmental factors such as temperature, humidity, and light. The standard stock solution of RIV (1000 $\left.\mu \mathrm{g} \mathrm{mL}^{-1}\right)$ prepared in ACN:Water $(80: 20 \mathrm{v} / \mathrm{v})$ was divided into two volumetric flasks $(5 \mathrm{~mL})$. These volumetric flasks were prevented from daylight and the first one was kept at room temperature, while the second one was kept at $4{ }^{\circ} \mathrm{C}$ inside the refrigerator. The stability of RIV at room temperature was evaluated in short term period $(24 \mathrm{~h})$, while the stability at $4{ }^{\circ} \mathrm{C}$ was evaluated for $72 \mathrm{~h}$ (short-term) and 1 month (long-term). The solutions were then diluted with mobile phase to $20 \mu \mathrm{g} \mathrm{mL}^{-1}$ and injected into the HPLC system.

\section{RESULTS AND DISCUSSION}

For developing and validating an HPLC method, the most common approach is to optimize the mobile phase composition after an appropriate column has been selected (Synder et al., 1997). RIV is a non-hygroscopic powder only slightly soluble in organic solvents and it is practically insoluble in water and aqueous media. According to our observation, RIV was slightly dissolved in methanol $(\mathrm{MeOH})$ on the preparation of standard stock solutions process. Therefore, the solubility of RIV was tested simply in various organic solvents in the initial experiments and it was concluded that RIV was clearly soluble in acetonitrile (ACN). Thus, it was decided to use the mixture of $\mathrm{ACN}$ and water in different proportion on the separation of RIV through C18 column. Since caffeine could be eluted with ACN:water mixture without using any buffer and it is an easy to find chemical for quality control laboratories, it was used as the internal standard (IS) for the experiments. A well-defined peak for caffeine was observed at $2.21 \mathrm{~min}$. under the experimental conditions. Even though the column temperature is an important parameter on separation of organic compounds by HPLC, the effect of the solvent strength is usually stronger than the effect of temperature on solute retention (Cuiru et al., 2005). It was seen that changing the column temperature between $30-40{ }^{\circ} \mathrm{C}$, changed the retention time of RIV not more than $5 \%$ and did not effect the retention time of IS noticeably. According to the results, it was obvious that RIV could be easily separated and analyzed less than 4 minutes in various conditions given in Table I. However, it was observed that better peaks shapes were obtained by increasing the temperature of the column. Since, the backpressure of the column was tolerable, the flow rate was kept at $1.2 \mathrm{~mL} \mathrm{~min}^{-1}$ to improve the efficiency besides decreasing the retention time. In conclusion, it was decided to use $\mathrm{ACN}$-Water ratio as 55:45 (v/v) at $40{ }^{\circ} \mathrm{C}$ to perform the analyses. The UV Spectrum of the RIV in mobile phase shows clearly that $249 \mathrm{~nm}$ is better to use in to observe the maximum absorbance while it is being prevented from interference coming from matrix components. The chromatograms of standard, tablet, analytical placebo solutions and RIV solution degraded at high temperature taken under optimum conditions are given in Figure 2.

\section{System Suitability}

The system suitability test was applied to the chromatograms taken under optimum conditions to check various parameters such as column efficiency (plates), peak tailing, capacity factor, and resolution. Suitable resolution ( $>1.5)$ and column efficiency $(>2000)$ were achieved for the proposed method while the total analysis time was shorter than 4 minutes. The system suitability results are given in Table II. The RSD of six consecutive injections was found to be $0.25 \%$, and $0.28 \%$ for IS and $\mathrm{RIV}$, respectively. All these results assure the adequacy of 
TABLE I - Retention time of IS and RIV on various conditions of mobile phase composition and chromatographic column temperature

\begin{tabular}{lcccccc}
\hline \multirow{2}{*}{ Condition $^{\mathrm{a}}$} & \multicolumn{2}{c}{ Mobile Phase Composition } & Temperature & \multicolumn{2}{c}{ Flow Rate } & \multicolumn{2}{c}{ Retention Time } \\
\cline { 2 - 6 } & $\mathrm{ACN}$ & $\mathrm{H}_{2} \mathrm{O}$ & ${ }^{\circ} \mathrm{C}$ & $\mathrm{mL} \mathrm{min}^{-1}$ & IS & RIV \\
\hline 1 & 60 & 40 & 40 & 1.20 & 2.167 & 2.976 \\
2 & 55 & 45 & 40 & 1.20 & 2.216 & 3.371 \\
3 & 50 & 50 & 40 & 1.20 & 2.268 & 3.965 \\
4 & 60 & 40 & 35 & 1.20 & 2.166 & 3.004 \\
5 & 55 & 45 & 35 & 1.20 & 2.214 & 3.430 \\
6 & 50 & 50 & 35 & 1.20 & 2.270 & 4.061 \\
7 & 60 & 40 & 30 & 1.20 & 2.168 & 3.061 \\
8 & 55 & 45 & 30 & 1.20 & 2.208 & 3.491 \\
9 & 50 & 50 & 30 & 1.20 & 2.271 & 4.147 \\
\hline
\end{tabular}

${ }^{\mathrm{a}}$ Condition 2 is selected to perform the analysis
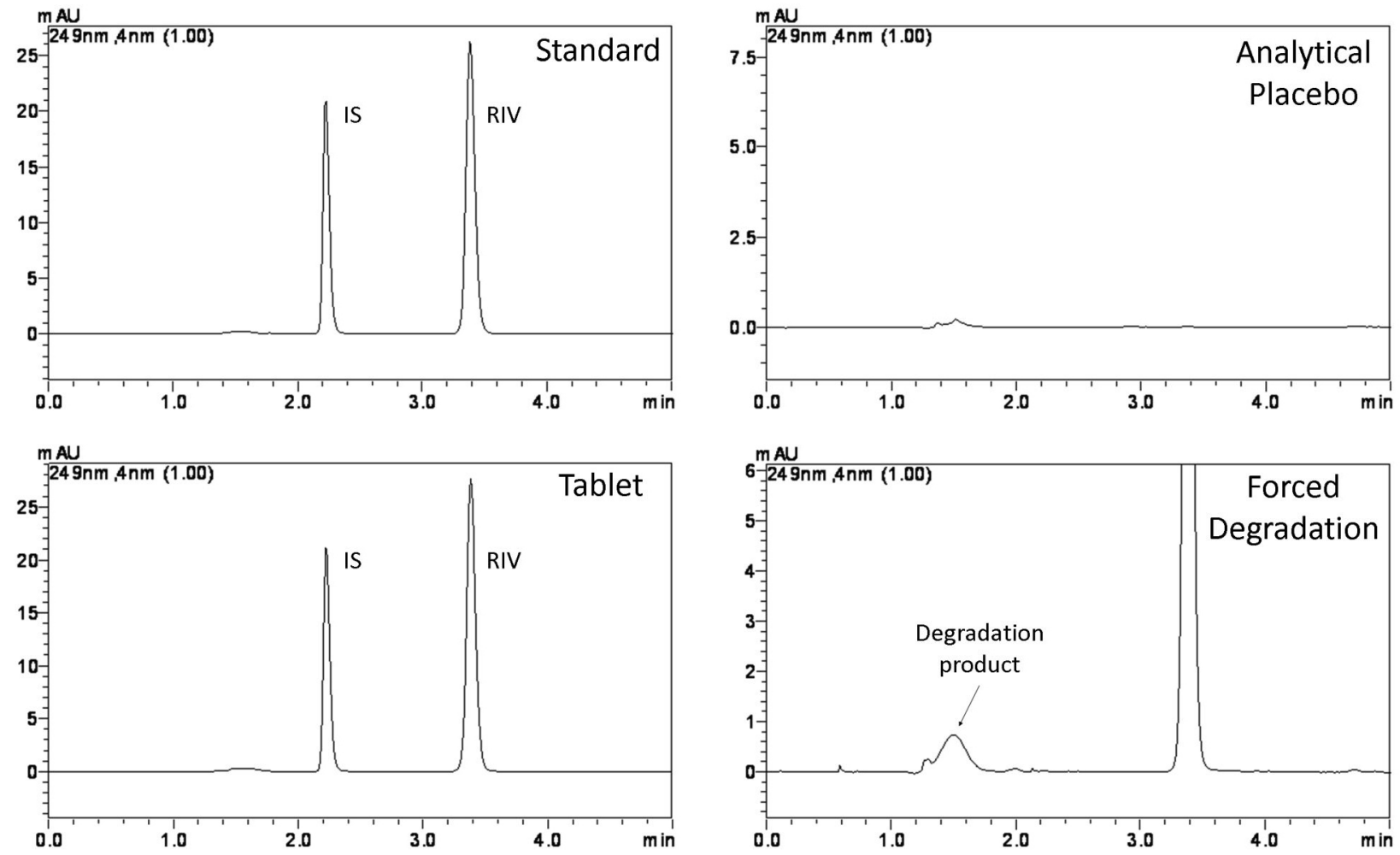

FIGURE 2 - Representative chromatograms obtained under the optimum chromatographic conditions for RIV standard, RIV tablet, analytical placebo solutions and RIV solution degraded at high temperature.

the proposed HPLC method for routine analysis of RIV.

\section{Method validation}

The proposed method was validated as to selective, linearity range, sensitivity, precision, accuracy, robustness and ruggedness according to the $\mathrm{ICH}$ guideline $(\mathrm{ICH}$, 2005).

\section{Forced degradation and stability studies}

The stability of RIV in aqueous solutions was investigated for two different purposes. The first one was to identify the stability of RIV and to show the selective analysis of RIV in various extreme stress conditions. The second one was to clarify the stability of standard solutions for short and long term at room temperature and 
TABLE II - System suitability parameters for the proposed method

\begin{tabular}{lcc}
\hline & RIV & IS \\
\hline Retention Time (min) & 3.37 & 2.21 \\
Capacity Factor (k') & 1.32 & 0.52 \\
Efficiency (N) & 7997 & 6369 \\
Peak Symmetry & 1.18 & 1.39 \\
Resolution & 8.9 & \\
\hline
\end{tabular}

inside refrigerator. The ICH guideline entitled stability testing of drug substances and products requires the stress testing to be carried out to elucidate the inherent stability characteristics of the active substance, and provide a rapid identification of differences that might result from changes in the manufacturing processes or source sample ( $\mathrm{ICH}, 2005)$. The aim is to quantify the standard drug alone and resolve its degradation products (Bakshi et al., 2002). As described in the experimental section, different stress conditions were applied: high temperature, acidbase hydrolysis and irradiation with UV light. Under all these conditions the degradation products were observed at $1.35 \mathrm{~min}$ (Figure 2). The method was able to separate completely the degradation products from the intact RIV. As shown in Figure 2, it is confirmed the selectivity of the proposed method with the presence of the degradation products. Stability studies of RIV at room temperature for $24 \mathrm{~h}, 4^{\circ} \mathrm{C}$ refrigeration temperature for $72 \mathrm{~h}$ (short-term) and 1 month (long-term) were also investigated. Forced degradation and stability studies show that RIV was stable at root temperature for $24 \mathrm{~h}$ and stable at $4{ }^{\circ} \mathrm{C}$ refrigeration temperature at least for 1 month, but not stable in acidic and alkaline medias and also not stable in high temperature and under the UV light. The forced degradation and stability results are given in Table III.

\section{Selectivity}

Selectivity of a method refers to the extent to which it can determine particular analyte(s) in a complex mixture without interference from other components in the mixture. Selectivity of the method was evaluated by preparing the analytical placebo sample, standard solution and sample of commercial pharmaceutical formulation. A solution of analytical placebo (containing all the tablet excipients except RIV) was prepared as given in the sample preparation procedure and injected into the HPLC system. The placebo chromatograms did not show any other peaks, thus, it was confirmed the selectivity of the method. The peak purities confirmed that the peaks on the standard solutions, tablet solutions and forced degradation solution are not interfered coming from matrix components. The retention times of peaks and peak areas were identical for the standard solutions and the tablet solutions and the method was capable of separating RIV and IS from forced degradation products. The chromatograms of standard, tablet, placebo and forcedly degraded RIV solutions were given in Figure 2.

\section{Linearity}

The linearity of an analytical procedure is its ability (within a given range) to obtain test results, which are directly proportional to the concentration (amount) of analyte in the sample. Calibration curve was constructed for RIV standards by plotting the concentrations versus peak area ratios. The graph proved that the method was linear up to $40 \mu \mathrm{g} \mathrm{mL}^{-1}$. Eight different standard solutions within the linear range containing 5.0, 10.0, 20.0, 25.0, $30.0,35.0$ and $40 \mu \mathrm{g} \mathrm{mL}^{-1}$ of RIV and $40 \mu \mathrm{g} \mathrm{mL}^{-1}$ of IS were prepared and injected into the HPLC system. The linearity was evaluated by linear regression analysis and the regression equations were calculated from the calibration graphs, along with the standard deviations of the slope $(\mathrm{Sb})$ and intercept $(\mathrm{Sa})$ of the calibration curve (Table IV).

\section{Sensitivity}

Limit of detection (LOD) and quantification (LOQ)

TABLE III - Recuperation (\%) of RIV ${ }^{\mathrm{a}}$ after the exposition on various conditions of temperature, $\mathrm{pH}$ and UV light

\begin{tabular}{|c|c|c|c|c|c|c|c|}
\hline Condition & $\begin{array}{c}\text { Room } \\
\text { Temperature }\end{array}$ & Refrigerator & Temperature & $\begin{array}{c}\text { Acidic } \\
\text { Solution }\end{array}$ & Basic Solution & $\begin{array}{c}\text { High } \\
\text { temperature }\end{array}$ & UV light \\
\hline Temperature & $25^{\circ} \mathrm{C}$ & $4^{\circ} \mathrm{C}$ & & $40^{\circ} \mathrm{C}$ & $40^{\circ} \mathrm{C}$ & $80^{\circ} \mathrm{C}$ & $25^{\circ} \mathrm{C}$ \\
\hline Time & $24 \mathrm{~h}$ & $72 \mathrm{~h}$ & 1 month & $2 \mathrm{~h}$ & $2 \mathrm{~h}$ & $2 \mathrm{~h}$ & $24 \mathrm{~h}$ \\
\hline Stability $(\%)^{\mathrm{b}}$ & $100.5 \pm 0.1$ & $100.1 \pm 0.2$ & $99.0 \pm 0.2$ & $83.2 \pm 0.1$ & $83.0 \pm 0.2$ & $77.7 \pm 0.2$ & $35.1 \pm 0.2$ \\
\hline
\end{tabular}

${ }^{a}$ RIV solutions were prepared as described in experimental section and prevented from daylight. ${ }^{b}$ Stability results are given as Recovery $(\%) \pm$ RSD while $\mathrm{n}=6$ and the added concentration of RIV is $20 \mu \mathrm{g} \mathrm{mL}^{-1}$ 
TABLE IV - Linearity of RIV analyses by the developed method

\begin{tabular}{lccccccc}
\hline Method & Range $\left(\mu \mathrm{g} \mathrm{mL}^{-1}\right)$ & Calibration Curve $^{\mathrm{a}}$ & $\mathrm{Sa}$ & $\mathrm{Sb}$ & $\mathrm{R}^{2}$ & $\mathrm{LOQ}$ & $\mathrm{LOD}$ \\
\hline HPLC & $5.0-40.0$ & $\mathrm{y}=0.0952 \mathrm{x}-0.0330$ & 0.0007 & 0.0183 & 0.9997 & 0.005 & 0.001 \\
\hline
\end{tabular}

${ }^{a}$ Based on six calibration curves where y: peak area ratio and $\mathrm{x}$ : concentration of RIV as $\mu \mathrm{g} \mathrm{mL} \mathrm{mL}^{-1}$; Sa: Standard error of intercept and $\mathrm{Sb}$ : Standard error of slope; $\mathrm{R}^{2}$ : Regression coefficient; LOQ: Limit of quantitation; LOD: Limit of detection

are estimated from the signal-to-noise ratio. The detection limit is defined as the lowest concentration level resulting in a peak height of three times the baseline noise. The quantitation limit is defined as the lowest concentration level that provided a peak height with a signal-to-noise ratio higher than 10 , with precision (RSD\%) and accuracy (Bias\%) within $\pm 10 \%$. LOD and LOQ values of HPLC method were determined to be 0.001 and $0.005 \mu \mathrm{g} \mathrm{mL}^{-1}$, respectively (Table IV).

\section{Precision and Accuracy}

Accuracy of the assay method was determined for both intra-day and inter-day variations using the six times analysis of the quality control samples. Three different concentrations of standard RIV solutions (within the linear range) were analyzed on six consecutive days (inter-day precision) and six times within the same day (intra-day precision). The obtained values for relative standard deviation (RSD) and Bias of intra- and inter-day studies indicated that the precision and accuracy of the method were satisfactory. The results are summarized in Table V.

\section{Recovery}

In order to know whether the excipients in the pharmaceutical formulations interfere with the analysis, the recovery tests were performed by standard addition technique. Three concentration levels were selected and known amounts of RIV standard solutions were added into the tablet solutions. The final concentrations were within the linear range. These solutions were prepared three times and analyzed through the developed method. Comparison of the intercepts of calibration curve $(0.0952 \pm 0.007$ (mean $\pm \mathrm{SE}))$ with standard additions technique $(0.0936 \pm 0.0201$ (mean $\pm \mathrm{SE}))$ indicates that they were identical and there was no interference coming from matrix components. The other perspective on recovery studies was to analyze synthetic tablet solutions by the proposed method. Synthetic tablet solutions were prepared six times and analyzed by the developed method and $97.89 \pm 0.68$ percent of the standard RIV were recovered from synthetic tablet solutions.

\section{Robustness}

The robustness of an analytical procedure is a measure of its capacity to remain unaffected by small but deliberate variations in method parameters and provides an indication of its reliability during normal usage. The variations on column temperature $\left( \pm 5{ }^{\circ} \mathrm{C}\right)$ and ratio of organic content in the mobile phase $( \pm 5 \%$ on $\mathrm{ACN}$ volume) did not have any significant effect on response. The peak area ratios were changed relatively between $99.8-102.4 \%$ within these small changes on mobile phase component and column temperature. The results were evaluated statistically, and there were no significant differences $(p>0.05)$ within the results.

\section{Reproducibility}

Applying same procedures by two different operators showed the ruggedness of the developed method. The analysis results having no significant difference indicate that the proposed method is robust.

TABLE V - Precision and accuracy of the developed method

\begin{tabular}{|c|c|c|c|c|c|c|c|}
\hline & \multirow{2}{*}{$\begin{array}{c}\text { Added } \\
\left(\mu \mathrm{g} \mathrm{mL} L^{-1}\right)\end{array}$} & \multicolumn{3}{|c|}{ Intra-day } & \multicolumn{3}{|c|}{ Inter-day } \\
\hline & & $\begin{array}{c}\text { Found }^{\mathrm{a}} \\
\left(\mu \mathrm{g} \mathrm{mL}^{-1}\right)\end{array}$ & $\begin{array}{c}\text { Precision }^{b} \\
\text { RSD } \% \\
\end{array}$ & $\begin{array}{c}\text { Accuracy }^{c} \\
\text { Bias \% }\end{array}$ & $\begin{array}{c}\text { Found } \\
\left(\mu \mathrm{g} \mathrm{mL}^{-1}\right)\end{array}$ & $\begin{array}{c}\text { Precision } \\
\text { RSD \% } \\
\end{array}$ & $\begin{array}{c}\text { Accuracy } \\
\text { Bias } \% \\
\end{array}$ \\
\hline \multirow[t]{3}{*}{ RIV } & 10 & $10.26 \pm 0.13$ & 2.15 & 2.56 & $9.80 \pm 0.08$ & 1.33 & -1.98 \\
\hline & 20 & $20.15 \pm 0.16$ & 1.34 & 0.74 & $20.23 \pm 0.35$ & 3.01 & 1.16 \\
\hline & 35 & $35.15 \pm 0.30$ & 1.49 & 0.41 & $35.06 \pm 0.11$ & 0.52 & 0.16 \\
\hline
\end{tabular}

${ }^{\mathrm{a}}$ Found: mean \pm standard error $(\mathrm{n}=6)$; ${ }^{\mathrm{b} S \mathrm{R}}$ : Relative standard deviation; Bias: [(Found - Added)/Added] x 100 


\section{Application of the developed method}

The validated method was applied for the determination of RIV in commercially available Xarelto ${ }^{\circledR}$ $(10 \mathrm{mg})$ tablets. Figure 2 illustrates a typical type of HPLC chromatogram of tablet solution of RIV at a retention time 3.37 min with no interference of excipients present in tablets. The tablet analysis results were given in Table VI. The results of the assay $(n=6)$ yielded $100.94 \%$ $(\mathrm{RSD}=1.17$ and $\mathrm{SE}=0.53)$ of the labeled claim. These results indicate that the method is selective for the analysis RIV without interference of the excipients. The low RSD value with proper accuracy indicates the suitability of this method for the routine analysis of RIV.

TABLE VI - Tablet analysis results

\begin{tabular}{lcc}
\hline \multirow{2}{*}{ Tablet Solutions } & \multicolumn{2}{c}{ Xarelto $^{\circledR}$ Tablets (10 mg RIV) } \\
\cline { 2 - 3 } & RIV $(\mathrm{mg})$ & Recovery (\%) \\
\hline 1 & 10.17 & 101.68 \\
2 & 9.91 & 99.14 \\
3 & 10.00 & 100.01 \\
4 & 10.17 & 101.66 \\
5 & 10.23 & 102.26 \\
6 & 10.09 & 100.90 \\
Mean $^{ \pm}$SE & $10.09 \pm 0.05$ & $100.94 \pm 0.48$ \\
RSD $^{\mathrm{a}}$ & \multicolumn{2}{c}{1.17} \\
Bias $^{\mathrm{b}}$ & \multicolumn{2}{c}{0.94} \\
\hline
\end{tabular}

${ }^{\mathrm{a}} \mathrm{RSD}$ : Relative standard deviation; ${ }^{\mathrm{b}}$ Bias : [(Found-Added)/Added] $\mathrm{x} 100$

\section{CONCLUSION}

In the present study, an attempt was made to develop a simple, accurate, selective and sensitive RP-HPLC method of RIV in pharmaceutical analysis. This method is the only reported method up to date for the determination of RIV in pharmaceutical dosage forms. The method was validated for selectivity, accuracy, linearity, precision (inter-day and intra-day), sensitivity, robustness and ruggedness in accordance with ICH guidelines. The results from stress testing, including separation of the degradation product and quantification of RIV after exposure to stress conditions show the method is stability-indicating and capable of determining RIV in presence of its degradation products, which indicates the selectivity of the method. A simple mobile phase without preparation of any buffer solution or adding ion-pairing agents and a short run time are advantageous and make this method suitable for routine analysis of large number of samples per day.

\section{ACKNOWLEDGEMENTS}

The authors are highly grateful to Bayer Türk Kimya San. Ltd. Şti., Istanbul, Turkey, for providing the drug samples.

\section{REFERENCES}

BAKSHI, M.; SINGH, S. Development of validated stabilityindicating assay methods-critical review. J. Pharm. Biomed. Anal., v.28, p.1011-1140, 2002.

CUIRU, Z.; GOODALL, D.M.; WREN, S.A.C. Elevated temperature HPLC: Principles and applications to small molecules and biomolecules. LCGC Asia Pacific, v.8, p.48-59, 2005.

DONG, M. W. Handbook of pharmaceutical analysis by HPLC. Elsevier: United Kingdom, 2005. v.6, p.2-3

DUGGAN, S.T.; SCOTT, L.J.; PLOSKER, G.L. Rivaroxaban a review of its use for the prevention of venous thromboembolism after total hip or knee replacement surgery. Drugs, v.69, p.1829-1851, 2009.

INTERNATIONAL CONFERENCE ON HARMONIZATION (ICH). Text on validation of analytical procedure: methodology: Q2(R1), 2005. Available at: <http://www. ich.org> Accessed on: 19 May 2012.

PERZBORN, E.; KUBITZA, D.; MISSELWITZ, F. Rivaroxaban: A novel, oral, direct factor Xa inhibitor in clinical development for the prevention and treatment of thromboembolic disorders. Hämostaseologie, v.27, p.282$289,2007$.

ROHDE, G. Determination of rivaroxaban - a novel, oral, direct Factor Xa inhibitor - in human plasma by high-performance liquid chromatography-tandem mass spectrometry. $J$. Chromatogr. B., v.872, p.43-50, 2008.

SNYDER, L.R.; GLAJCH, J.L.; KIRKLAND, J.J. Practical HPLC method development. 2ed. New York: John Wiley \& Sons, 1997. Chapter 1.2

TERRY, C.; SUM, L. Rivaroxaban: an oral direct factor Xa inhibitor for the prevention of thromboembolism. Cardiol. Rev., v.17. p.192-197, 2009. 
WORLD HEALTH ORGANIZATION. WHO technical report series no. 957, WHO expert committee on specifications for pharmaceutical preparations, Forty-fourth report, 2010. Available at: <http://www.who.int/en/>. Accessed on: 19 May 2012.

Received for publication on $19^{\text {th }}$ June 2012 Accepted for publication on $08^{\text {th }}$ February 2013 